\title{
Management of Late Leaf Spot of Peanut with Benomyl and Chlorothalonil: A Study in Preserving Fungicide Utility
}

\author{
A. K. Culbreath, Professor, Department of Plant Pathology, The University of Georgia Coastal Plain Experiment \\ Station, Tifton 31793-0748; K. L. Stevenson, Associate Professor, Department of Plant Pathology, The University \\ of Georgia, Athens 30602-7274; and T. B. Brenneman, Professor, Department of Plant Pathology, The University \\ of Georgia Coastal Plain Experiment Station, Tifton
}

\begin{abstract}
Culbreath, A. K., Stevenson, K. L., and Brenneman, T. B. 2002. Management of late leaf spot of peanut with benomyl and chlorothalonil: A study in preserving fungicide utility. Plant Dis. 86:349-355

Recent registration of sterol biosynthesis inhibitor and strobilurin fungicides for control of early (Cercospora arachidicola) and late (Cercosporidium personatum) leaf spot diseases of peanut (Arachis hypogaea) has renewed interest in the potential for loss of disease control due to fungicide resistance. The objectives of this study were to use the systemic fungicide benomyl, the protectant fungicide chlorothalonil, and late leaf spot of peanut as a model system to compare fungicide application strategies for fungicide resistance management. Field experiments were conducted at Tifton and Plains, GA, in 1995 and 1996 to determine the effects of alternate applications, mixtures, and alternating block applications of chlorothalonil and benomyl compared with full-season applications of two rates of chlorothalonil and two rates of benomyl alone on late leaf spot of peanut and on the proportion of the pathogen population resistant to benomyl following the various regimes. Tank mix combinations of half rates of the two fungicides and alternations of the full rates of the two fungicides provided better $(P \leq 0.05)$ control of late leaf spot than full-season applications of either rate of benomyl alone, and were comparable to full rates of chlorothalonil alone. Neither tank mixes nor alternating sprays prevented an increase in the relative frequency of benomyl-resistant isolates compared with other treatments in which benomyl was used. Both mixtures and alternate applications of chlorothalonil and benomyl were effective for management of leaf spot in fields where benomyl alone did not provide season-long leaf spot control.
\end{abstract}

Additional keywords: fungicide insensitivity, groundnut

In the southeastern United States, control of leaf spot diseases of peanut (Arachis hypogaea L.) caused by Cercospora arachidicola S. Hori (teleomorph $M y$ cosphaerella arachidis Deighton) and Cercosporidium personatum (Berk. \& M. A. Curtis) Deighton (teleomorph $M y$ cosphaerella berkeleyi Jenk.) is largely dependent upon multiple applications of fungicides. For over two decades prior to 1994, peanut growers in Alabama, Georgia, and Florida relied almost exclusively on chlorothalonil, a broad spectrum protectant fungicide, for control of leaf spot diseases. Registration of systemic sterol biosynthesis inhibitor (SBI) fungicides (tebuconazole and propiconazole) and strobilurin fungi-

Corresponding author: A. K. Culbreath

E-mail: spotwilt@tifton.cpes.peachnet.edu

This research was supported in part by Georgia peanut growers through grants from the Georgia Agric. Commodity Commission for Peanuts, and in part by Dupont de Nemours.

Accepted for publication 26 October 2001.

Publication no. D-2002-0212-05R

(C) 2002 The American Phytopathological Society cides (azoxystrobin and trifloxystrobin) have provided new options for disease management. However, these fungicides all have highly specific modes of action, which has prompted renewed interest in prevention and management of fungicide resistance in foliar pathogens of peanut.

Application regimes of spray mixtures, alternating sprays, or alternating blocks of sprays of these fungicides with chlorothalonil have been recommended as resistance prevention or management strategies in peanut (3). Currently, tebuconazole is applied in a four-spray block corresponding to sprays 3 to 6 in a seven-spray regime. Chlorothalonil typically is applied at sprays 1,2 , and 7 in this regime. Propiconazole is recommended primarily for use when mixed with chlorothalonil for control of foliar diseases (3). This mixture is sometimes used for the first two sprays in fields where tebuconazole is used for sprays 3 to 6 . However, use of propiconazole and tebuconazole in the same field and year has not been recommended due to concern about selecting for pathogen populations with reduced sensitivity to SBI fungicides. This recommendation is based in part on Fungicide Resistance Action Committee guidelines for SBI fungicides $(3,5)$.
Currently, reduced sensitivity to SBI or strobilurin fungicides in pathogens of peanut is not a problem. Therefore, the suggested fungicide use patterns for preventing or managing potential problems with reduced sensitivity in peanut have been developed based on theory or results from other pathosystems $(5,12,21,22)$. Various timing regimes and methods of application have been proposed and examined in efforts to maximize control of multiple diseases and to minimize the risk of developing pathogen populations with reduced sensitivity to these fungicides $(5,12,21,22)$. Direct comparisons of the various regimes for prevention or management of fungicide resistance in any pathosystem are rare. The relative efficacy of the different regimes for preventing loss of control of leaf spot to SBI- or strobilurin-resistant isolates in peanut may not be conclusively determined until resistant isolates are found.

Benomyl is a benzimidazole fungicide that was very effective for control of $\mathrm{Cer}$ cospora arachidicola and Cercosporidium personatum on peanut (15). However, severe problems with benomyl resistance in populations of both leaf spot pathogens developed very soon after benomyl use on peanut began in the early $1970 \mathrm{~s}$ $(1,7,14,20)$. As a result, benomyl has not been used for leaf spot control on peanut in the southeastern United States for over 25 years. Despite this abstinence, significant populations of Cercospora arachidicola and Cercosporidium personatum that are resistant to benomyl still persisted in 1988 (4). Due to the availability of alternative fungicides, resistance to benomyl is no longer a problem for the peanut industry. However, the presence of benomyl resistance in current pathogen populations provides a model system for examining the effectiveness of fungicide application regimes for fungicide resistance management.

One purpose of this study was to use benomyl and chlorothalonil to compare mixtures, alternating sprays, and alternating block applications of single-site (benomyl) and multiple-site (chlorothalonil) fungicides for control of peanut leaf spot in fields where a significant portion of the pathogen populations are benomyl resistant. A second objective was to determine the treatment effects on incidence of benomyl resistance in the $C$. personatum popu- 
lations. The treatment regimes evaluated in these studies are analogous to either current use patterns for SBI and strobilurin fungicides or proposed use patterns for experimental fungicides that may be used on peanut in the future.

\section{MATERIALS AND METHODS}

Disease management. Florunner peanut $(78.4 \mathrm{~kg}$ of seed $/ \mathrm{ha}$ ) was planted in a field of Tifton loamy sand $(\mathrm{pH} 5.8)$ at the Coastal Plain Experiment Station, Lang Farm, Tifton, GA on 24 May 1995 and 24 May 1996. The same cultivar $(112 \mathrm{~kg}$ of seed/ha) was planted in a field of Faceville sandy loam (pH 5.8) at the Southwest Georgia Branch Station, Plains, GA on 27 April 1995 and 26 April 1996. All fields had been planted to cotton (Gossypium hirsutum L.) the previous year but had been planted to peanut 2 years prior to the experiment. Different fields were used at each location in the 2 years. Calcitic limestone $(2,240 \mathrm{~kg} / \mathrm{ha})$ was broadcast on all fields approximately 60 days prior to planting and fertilizer (2-9-18) at $896 \mathrm{~kg} / \mathrm{ha}$ was broadcast approximately 30 days prior to planting. All fields were turned with a moldboard plow and bedded 12 to 15 days prior to planting. Benefin $(1.7 \mathrm{~kg}$ a.i/ha) and metoalochlor (2.2 kg a.i./ha) herbicides were applied broadcast to the soil and incorporated after fields were bedded prior to planting.

Benomyl had not been applied to peanut in any of these fields in over 15 years. Plots received aldicarb or phorate insecticide $(0.75$ to $1.0 \mathrm{~kg}$ a.i./ha) in-furrow at planting. Plots were $7.3 \mathrm{~m}$ long in all tests. In Tifton, row spacing was a uniform 0.91 $\mathrm{m}$ (1.83-m bed). In Plains, rows were 0.71 $\mathrm{m}$ apart within the bed and $0.91 \mathrm{~m}$ between rows in adjacent beds (1.63-m bed). Plots were separated by two nonsprayed border rows, and blocks were separated by $2.4-\mathrm{m}$ fallow alleys. A randomized complete block experimental design with four replications was used in all tests except at the Tifton location in 1996, where six replications were used.

Treatments consisted of (i) nontreated control; (ii) chlorothalonil (Bravo WeatherStik; Syngenta Crop Protection, Inc, Greensboro, NC) at $0.63 \mathrm{~kg}$ a.i./ha, sprays 1 to 7 ; (iii) chlorothalonil at $1.26 \mathrm{~kg}$ a.i./ha, sprays 1 to 7; (iv) benomyl (Benlate 50 WP; Dupont de Nemours, Wilmington, DE) at $0.28 \mathrm{~kg}$ a.i./ha, sprays 1 to 7 ; (v) benomyl at $0.14 \mathrm{~kg}$ a.i./ha, sprays 1 to 7 ; (vi) alternation of chlorothalonil at $1.26 \mathrm{~kg}$ a.i./ha, sprays $1,3,5$, and 7 , with benomyl at $0.28 \mathrm{~kg}$ a.i./ha, sprays 2, 4, and 6; (vii) tank mix combination of chlorothalonil at $0.63 \mathrm{~kg}$ a.i./ha and benomyl at $0.14 \mathrm{~kg}$ a.i./ha, sprays 1 to 7; (viii) block applications of chlorothalonil at $1.26 \mathrm{~kg}$ a.i./ha, sprays 1,2 , and 7 , and benomyl at $0.28 \mathrm{~kg}$ a.i./ha, sprays 3 to 6 ; and (ix) block applications of tank mix combinations of chlorothalonil at $0.63 \mathrm{~kg}$ a.i./ha and beno- myl at $0.14 \mathrm{~kg}$ a.i./ha, sprays 1 and 2, benomyl at $0.28 \mathrm{~kg}$ a.i./ha, sprays 3 to 6 , and chlorothalonil at $1.26 \mathrm{~kg}$ a.i./ha, spray 7 . The $1.26 \mathrm{~kg} / \mathrm{ha}$ rate of chlorothalonil is the standard rate typically used for leaf spot management. Benomyl at $0.28 \mathrm{~kg} / \mathrm{ha}$ was used because it was reported in early studies to be very effective against early and late leaf spot (15).

At Tifton, fungicide applications were made 28, 42, 56, 69, 83, 96, and 112 days after planting (DAP) in 1995 and 35, 47, 61, 75, 89, 104, and 117 DAP in 1996. At Plains, fungicides were applied 43, 56, 68, 84, 97, 111, and 126 DAP in 1995 and 39, $52,67,84,96,111$, and 126 DAP in 1996. Fungicide applications were made using a multiple-boom tractor-mounted $\mathrm{CO}_{2}$-propellant sprayer. Each boom was equipped with three D3-23 hollow-cone spray nozzles per row. Fungicides were applied in 114 liters of water/ha at a pressure of $345 \mathrm{kPa}$.

Leaf spot intensity, which accounted for severity and defoliation, was assessed for entire plots by use of the Florida 1-to-10 scale, where $1=$ no leaf spot; $2=$ very few lesions on the leaves, none on the upper canopy; 3 = few lesions on the leaves, very few on the upper canopy; $4=$ some lesions with more on the upper canopy, $\approx 5 \%$ defoliation; $5=$ lesions noticeable even on upper canopy, $\approx 20 \%$ defoliation; $6=$ lesions numerous and very evident on upper canopy, $\approx 50 \%$ defoliation; $7=$ lesions numerous on upper canopy, $\approx 75 \%$ defoliation; $8=$ upper canopy covered with lesions, $\approx 90 \%+$ defoliation; $9=$ very few leaves remaining and those covered with lesions, some plants completely defoliated; and $10=$ plants completely defoliated and killed by leaf spot (6). Leaf spot intensity ratings were made $91,100,114$, and 125 DAP in 1995 and 94, 108, 122, and 137 DAP in 1996 at Tifton; and 98, 112, 126, and 137 DAP in 1995 and 84, 96, 111, 125, and 146 DAP in 1996 at Plains. Area under the disease progress curve (AUDPC) was calculated according to method of Shaner and Finney (19) using leaf spot intensity ratings and time in days.

Plants were dug and inverted 126 DAP in 1995 and 143 DAP in 1996 at Tifton, and 137 DAP in 1995 and 146 DAP in 1996 at Plains. Immediately after plants were inverted, loci of southern stem rot (Sclerotium rolfsii) were counted for each plot, where a locus represented $31 \mathrm{~cm}$ or less of linear row with one or more plants infected (16). Incidence of stem rot was calculated as the percentage of $31-\mathrm{cm} \mathrm{sec-}$ tions of row with symptoms of stem rot or signs of the pathogen. Plants were allowed to dry in the windrow, and pods were harvested 132 DAP in 1995 and 151 DAP in 1996 at Tifton, and 144 DAP in 1995 and 153 DAP in 1996 at Plains. Pod yields were determined for each plot after harvest pods were dried and adjusted to $12 \%$ (wt/wt) moisture for treatment comparisons.
Analysis of isolates. Late leaf spot was the predominant foliar disease in all tests. In all, 50 to 75 quadrifolioliate leaves with late leaf spot lesions were collected from each plot (26) for sensitivity assays at the time of the last leaf spot intensity rating, 125 and 137 DAP in Tifton and 137 and 146 DAP in Plains in 1995 and 1996, respectively. Approximately half were collected from each of the two rows, and leaves were taken from the entire length of the row. Leaves were collected from the middle to upper canopy when possible as suggested by Yoder et al. for monitoring resistance in Cercospora spp. (26). However, for treatments with few lesions, leaves with spots were collected lower in the canopy when necessary. Leaflets with late leaf spot lesions from each plot were incubated 24 to $36 \mathrm{~h}$ at room temperature in individual moist chambers. Conidia of Cercosporidium personatum present after incubation were collected using a cyclone spore collector. Conidia from each plot were collected in individual sterile test tubes. Suction was applied through the spore collector without collection tubes attached between samples to prevent mixing spores from different plots. Conidia were suspended in deionized water and sprayed onto dishes of $2.0 \%$ water agar without benomyl and water agar amended with benomyl at 0.1 and $0.5 \mu \mathrm{g} / \mathrm{ml}$. The 0.5 $\mu \mathrm{g} / \mathrm{ml}$ concentration was used by Clark et al. (7) and by Littrell (14) as a discriminatory concentration. Five dishes were used for the conidia from each plot. After $24 \mathrm{~h}$ at room temperature, conidia on each dish were examined microscopically for germination (showing obvious germ tube development). Conidia were examined and evaluated in the order in which they were encountered on the plate. Location of an evaluated conidium was marked on the plate to prevent recounting.

The number of conidia examined was dependent on the number of conidia available, with a minimum number of 40 conidia per treatment for each media concentration corresponding with numbers in early reports on benomyl resistance in Cercospora arachidicola (7). In 1995, few conidia were present on lesions from the Plains test; therefore, only 10 conidia were examined from each replication. Approximately 50 conidia were examined from each replication for the Tifton test. In 1996, 25 conidia were examined from each replication for both locations. The percentage of conidia germinating on the benomyl-amended and nonamended agar was calculated as an estimate of the relative frequency of benomyl-resistant isolates.

Each test was analyzed independently and across years and locations. Leaf spot severity, AUDPC, southern stem rot loci, yield, and conidia germination data were subjected to analysis of variance (23). Fisher's protected least significant difference (LSD) was calculated for mean sepa- 
rations within each test using $P \leq 0.05$. All subsequent reference to significant effects of factors, interactions, or differences among means indicates significance at $P \leq$ 0.05 unless otherwise stated.

\section{RESULTS}

Disease management. In both years, leaf spot epidemics were moderate at Tifton and moderate to heavy at Plains (Fig. 1). Late leaf spot was the predominant foliar disease during the later part of the season in both years. Location-treatment and year-treatment effects on final leaf spot severity and AUDPC were significant. When each test was analyzed independently, treatment effects were significant on AUDPC, final leaf spot intensity ratings, and yield. In all experiments, AUDPC values and final leaf spot intensity ratings were higher for the nontreated plots than for any other treatment (Table 1, Fig. 1).

Treatment differences among the various fungicide regimes were evident by the second or third evaluation date in all tests except in 1996 at Tifton (Fig. 1). Leaf spot final intensity ratings and AUDPC values also were consistently lower in plots treated with chlorothalonil at $1.26 \mathrm{~kg}$ a.i./ha than at $0.63 \mathrm{~kg}$ a.i./ha. At Tifton, full-season application of chlorothalonil at $0.63 \mathrm{~kg}$ a.i./ha resulted in final leaf spot ratings and AUDPC values similar to those of plants treated with benomyl at $0.28 \mathrm{~kg}$ a.i./ha in both years (Table 1). At Plains, application of either rate of benomyl alone resulted in higher final leaf spot intensity ratings than those of the low rates of chlorothalonil alone in both years. However, in 1996 at Plains, AUDPC values for benomyl at $0.28 \mathrm{~kg}$ a.i./ha were similar to those of chlorothalonil at $0.63 \mathrm{~kg}$ a.i./ha (Table 1). At both locations, final leaf spot ratings did not differ between the high and low rates of benomyl alone. At Plains, AUDPC values for benomyl at $0.28 \mathrm{~kg} / \mathrm{ha}$ were lower that for $0.14 \mathrm{~kg} / \mathrm{ha}$ in both years.

Both final leaf spot ratings and AUDPC values indicated that alternating applica- tions of high rates of chlorothalonil and benomyl provided leaf spot control that was better than that of full-season applications of the high rate of chlorothalonil at Tifton in 1995 (Table 1). Alternating these fungicides resulted in final leaf spot intensity ratings slightly higher than those of high rate of chlorothalonil alone at Plains in 1995, although AUDPC values did not differ for those treatments (Table 1). In both of the other tests, these two treatments resulted in similar final disease ratings, although AUDPC values were lower for the chlorothalonil-benomyl alternation treatment at Plains in 1996.

Use of mixtures of half rates of benomyl and chlorothalonil resulted in final leaf spot ratings and AUDPC values that were similar to those of the full rate of chlorothalonil alone, except at Tifton in 1995, when control achieved with the mixtures was better than that of chlorothalonil alone at $1.26 \mathrm{~kg} / \mathrm{ha}$ (Table 1). Final leaf spot intensity ratings did not differ between the alternation and mixture treat-

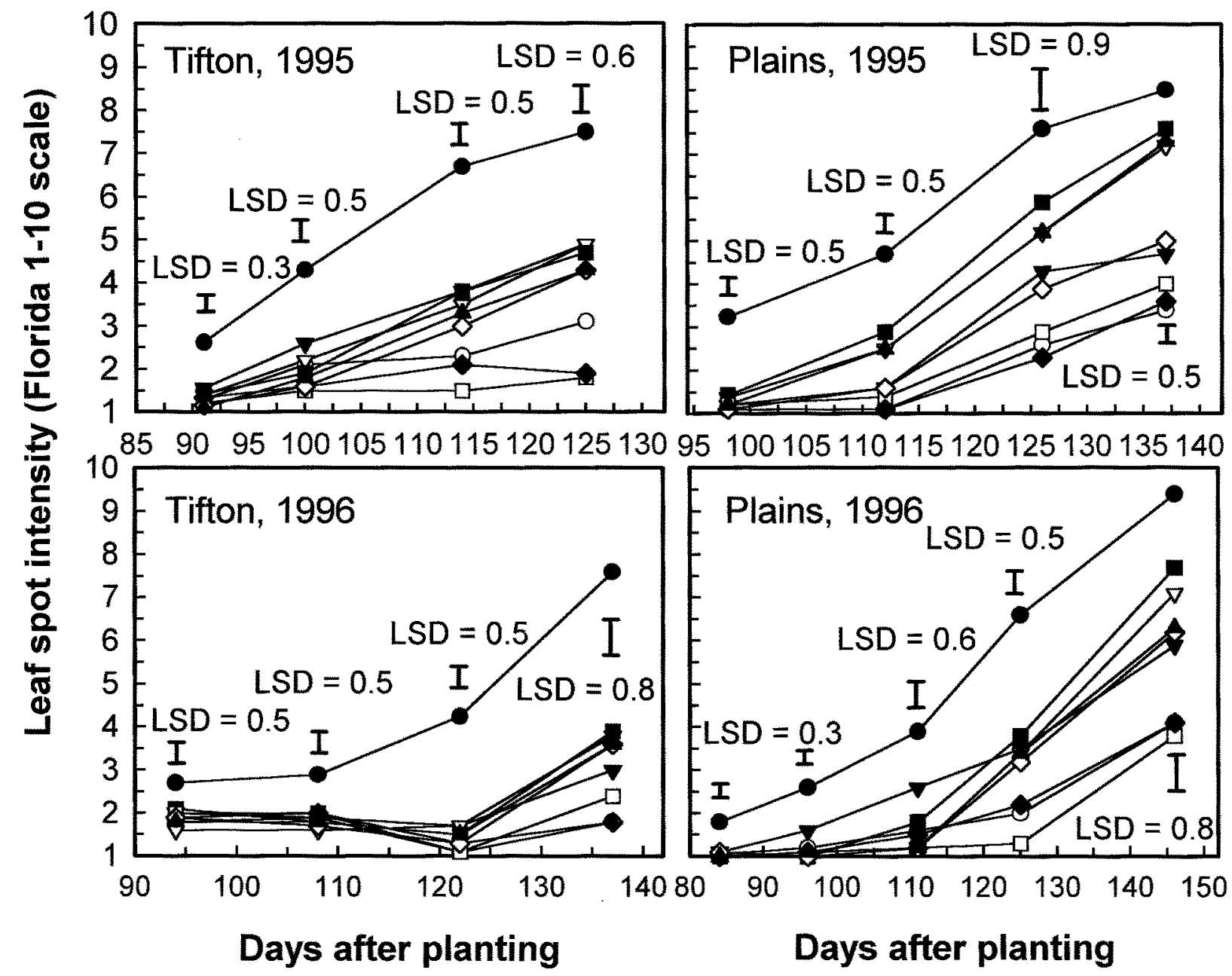

Fig. 1. Effect of treatment regimes of chlorothalonil (Chl) and benomyl (Ben) on disease progress of late leaf spot of peanut. Treatments included: (i) nontreated (closed circle); (ii) Chl at $1.26 \mathrm{~kg} / \mathrm{ha}$, sprays $1-7$ (open circle); (iii) Chl at $0.63 \mathrm{~kg} / \mathrm{ha}$, sprays 1-7 (closed downward triangle); (iv) Ben at 0.28 $\mathrm{kg} / \mathrm{ha}$, sprays 1-7 (open downward triangle); (v) Ben at $0.14 \mathrm{~kg} / \mathrm{ha}$, sprays 1-7 (closed square); (vi) alternate sprays of Chl at $1.26 \mathrm{~kg} / \mathrm{ha}, \mathrm{sprays} 1,3,5$, and 7, and Ben at $0.28 \mathrm{~kg} / \mathrm{ha}$, sprays 2, 4, and 6 (open square); (vii) mixtures of Chl at $0.63 \mathrm{~kg} / \mathrm{ha}$, and Ben at $0.14 \mathrm{~kg} / \mathrm{ha}$, sprays $1-7$ (closed diamond); (viii) block applications of Chl at $1.26 \mathrm{~kg} / \mathrm{ha}$, sprays 1,2, and 7, and Ben at $0.28 \mathrm{~kg} / \mathrm{ha}$, sprays 3 to 6 (open diamond); and (ix) block applications of Chl at $0.63 \mathrm{~kg} / \mathrm{ha}$ and Ben at $0.14 \mathrm{~kg} / \mathrm{ha}$, sprays 1,2, and 7 tank mixes followed by Ben at $0.28 \mathrm{~kg} / \mathrm{ha}$, sprays 3 to 6 (closed upward triangle). Least significant difference values were calculated at $P=0.05$. 
ments in any test, and AUDPC values for the two treatments were similar except at Plains in 1996, where the AUDPC values were lower in the alternation treatment. Both alternate application and mixture treatments had final leaf spot ratings that were better than either of the treatments where four consecutive applications of benomyl were made (Table 1). AUDPC values followed a similar trend except that, at Tifton in 1996, AUDPC values among these four treatments did not differ.

There were no consistent effects of any of the treatments on incidence of southern stem rot at Tifton, and no significant treatment effects on stem rot at Plains in either year. Therefore, data on that disease are not presented. Treatment effects of the fungicide regimes on yield were not consistent across the different tests (Table 1). In 1995 at Tifton, only the chlorothalonil-benomyl block application treatment had a yield that was greater than that of the control. In 1996 at Tifton, all treatments had yields greater than the control. Among the fungicide treatments, only benomyl at 0.14 $\mathrm{kg} / \mathrm{ha}$ and the alternate applications of chlorothalonil and benomyl had yields lower than that of chlorothalonil at 1.26 $\mathrm{kg} / \mathrm{ha}$. In 1995 at Plains, all treatments except benomyl at $0.14 \mathrm{~kg} / \mathrm{ha}$ had yields greater than the control (Table 1). No other fungicide regime other than benomyl at $0.14 \mathrm{~kg} / \mathrm{ha}$ had a yield that differed from chlorothalonil at $1.26 \mathrm{~kg} / \mathrm{ha}$. In 1996 at Plains, all fungicide treatments had yields greater than the control. Benomyl at 0.14 and $0.28 \mathrm{~kg} / \mathrm{ha}$ had yields lower than chlorothalonil at $1.26 \mathrm{~kg} / \mathrm{ha}$. Yields did not differ among any of the treatments with chlorothalonil alone or where both chlorothalonil and benomyl were used.

Analysis of isolates. Location-treatment and year-treatment effects on conidia germination were significant for both the 0.1 and $0.5 \mu \mathrm{g} / \mathrm{ml}$ concentrations. In 1995, there were few differences in germination among treatments for conidia from Tifton on benomyl agar at $0.1 \mu \mathrm{g} / \mathrm{ml}$. Germination rates ranged from $62 \%$ from plots treated with the low rate of chlorothalonil to $87 \%$ from plots treated with the low rate of benomyl alone (LSD = 9). However, at Plains, the germination rates on benomyl agar at $0.1 \mu \mathrm{g} / \mathrm{ml}$ among treatments that received no benomyl ranged from 18 to $35 \%$, compared with treatments that included benomyl, where germination rates ranged from 82 to $98 \%(\mathrm{LSD}=19)$. The $0.5 \mu \mathrm{g} / \mathrm{ml}$ concentration of benomyl provided separation of treatments. From both Tifton and Plains tests, percentages of conidia of $\mathrm{C}$. personatum that germinated on benomyl agar at $0.5 \mu \mathrm{g} / \mathrm{ml}$ were lower from plants treated with no fungicide or chlorothalonil alone than from any of the treatments that included benomyl (Fig. 2). Too few conidia were collected from plants that received alternate sprays of chlorothalonil and benomyl at Tifton to assay for that treatment effect on germination.

Germination of conidia among and within treatments was highly variable in 1996. At Tifton, germination rates of conidia on a $0.1 \mu \mathrm{g} / \mathrm{ml}$ concentration of benomyl ranged from 9 to $38 \%$ in the three treatments that received no benomyl, compared with a range of 53 to $95 \%$ among the treatments with benomyl $(\mathrm{LSD}=14)$. At Plains, germination rates on benomyl agar at $0.1 \mu \mathrm{g} / \mathrm{ml}$ ranged from 58 to $79 \%$ among the no-benomyl treatments, and from 42 to 94\% among treatments that received benomyl (LSD = 21). For the Tifton test, germination on benomyl agar at $0.5 \mu \mathrm{g} / \mathrm{ml}$ was lower for conidia from plots treated with no fungicide or chlorothalonil alone than for conidia from plants that received any of the treatments that included benomyl (Fig 2 ). No conidia from plants treated with either rate of chlorothalonil alone germinated on benomyl agar at $0.5 \mu \mathrm{g} / \mathrm{ml}$.

At Plains, too few conidia were collected from the low rate treatment of benomyl or the combination tank-mix benomyl block treatment to assay. Among the remaining treatments, germination rate for conidia from plots treated with benomyl alone at $0.28 \mathrm{~kg}$ a.i./ha did not differ from those of treatments receiving no benomyl.

\section{DISCUSSION}

Leaf spot intensity ratings in plots treated with benomyl alone and sensitivity assays of conidia indicated that benomylresistant populations were factors in all tests. Our findings corroborate earlier reports by Trivellas (25) and Brenneman and Jewell (4) that benomyl-resistant isolates of Cercosporidium personatum persisted in peanut fields in Georgia years after use of benomyl for leaf spot control was discontinued. Based on assays on water agar amended with benomyl at $0.5 \mu \mathrm{g} / \mathrm{ml}$, the percentage of benomyl-resistant isolates of $C$. personatum from treatments that received no benomyl in our tests ranged from

Table 1. Effect of fungicide and application regime on final leaf spot intensity ratings, area under the disease progress curve (AUDPC), and pod yield of peanut in Tifton and Plains, GA, in 1995 and 1996

\begin{tabular}{|c|c|c|c|c|c|c|c|c|c|c|c|c|c|c|}
\hline \multirow[b]{3}{*}{ Treatment $^{\mathrm{c}}$} & \multirow[b]{3}{*}{ Rate $^{\text {d }}$} & \multirow[b]{3}{*}{ Appl. ${ }^{\mathrm{e}}$} & \multicolumn{4}{|c|}{ Leaf spot final intensity ${ }^{a}$} & \multicolumn{4}{|c|}{ Leaf spot AUDPC ${ }^{b}$} & \multicolumn{4}{|c|}{ Pod yield (kg/ha) } \\
\hline & & & \multicolumn{2}{|c|}{ Tifton } & \multicolumn{2}{|c|}{ Plains } & \multicolumn{2}{|c|}{ Tifton } & \multicolumn{2}{|c|}{ Plains } & \multicolumn{2}{|c|}{ Tifton } & \multicolumn{2}{|c|}{ Plains } \\
\hline & & & 1995 & 1996 & 1995 & 1996 & 1995 & 1996 & 1995 & 1996 & 1995 & 1996 & 1995 & 1996 \\
\hline Nontreated & & & 7.5 & 7.6 & 8.5 & 9.5 & 371 & 357 & 458 & 636 & 2,887 & 3,084 & 3,220 & 2,643 \\
\hline Chlorothalonil & 1.26 & $1-7$ & 3.1 & 1.8 & 3.4 & 4.1 & 149 & 133 & 149 & 247 & 3,390 & 4,212 & 5,358 & 5,968 \\
\hline Chlorothalonil & 0.63 & $1-7$ & 4.9 & 3.0 & 4.7 & 5.9 & 221 & 176 & 220 & 379 & 3,147 & 4,347 & 5,350 & 5,691 \\
\hline Benomyl & 0.28 & $1-7$ & 4.9 & 3.8 & 7.2 & 7.1 & 204 & 173 & 298 & 343 & 2,513 & 3,881 & 4,569 & 4,724 \\
\hline Benomyl & 0.14 & $1-7$ & 4.7 & 3.9 & 7.6 & 7.7 & 202 & 182 & 332 & 389 & 3,130 & 3,724 & 3,968 & 4,529 \\
\hline Chlorothalonil & 1.26 & $1,3,5,7$ & & & & & & & & & & & & \\
\hline Benomyl & 0.28 & $2,4,6$ & 1.8 & 2.4 & 4.0 & 3.8 & 101 & 150 & 171 & 199 & 2,887 & 3,632 & 5,643 & 5,903 \\
\hline Chlorothalonil (tm) + & 0.63 & $1-7$ & & & & & & & & & & & & \\
\hline Benomyl (tm) & 0.14 & $1-7$ & 1.9 & 1.8 & 3.6 & 4.1 & 122 & 148 & 144 & 249 & 2,919 & 4,380 & 4,829 & 5,423 \\
\hline Chlorothalonil & 1.26 & $1,2,7$ & & & & & & & & & & & & \\
\hline Benomyl & 0.28 & 3 to 6 & 4.3 & 3.6 & 5.0 & 6.2 & 169 & 166 & 215 & 318 & 3,626 & 4,331 & 4,878 & 5,390 \\
\hline Chlorothalonil (tm) + & 0.63 & 1,2 & & & & & & & & & & & & \\
\hline Benomyl (tm) & 0.14 & 1,2 & & & & & & & & & & & & \\
\hline Benomyl & 0.28 & 3 to 6 & & & & & & & & & & & & \\
\hline Chlorothalonil & 1.26 & 7 & 4.3 & 3.6 & 7.3 & 6.3 & 179 & 174 & 296 & 328 & 2,951 & 3,849 & 4,553 & 5,309 \\
\hline $\operatorname{LSD}(P \leq 0.05)^{\mathrm{f}}$ & $\ldots$ & $\ldots$ & 0.6 & 0.8 & 0.5 & 0.8 & 24 & 31 & 28 & 43 & 619 & 412 & 1,281 & 1,008 \\
\hline
\end{tabular}

${ }^{a}$ Leaf spot severity was assessed by use of the Florida 1-to-10 scale, where $1=$ no leaf spot and $10=$ plants completely defoliated and killed by leaf spot.

b AUDPC for leaf spot was calculated for each plot using Florida 1-to-10 scale ratings. Four ratings were used in both locations in 1995 and in Tifton in 1996. Five ratings were made at Plains in 1996.

${ }^{\mathrm{c}}$ Fungicides applied in tank-mix combinations $=\mathrm{tm}$.

${ }^{\mathrm{d}}$ Fungicide application rate in $\mathrm{kg}$ a.i./ha.

e Appl. = spray timing applied at approximately 14-day intervals, where 1 represents the first spray, and 7 represents the last.

${ }^{\mathrm{f}} \mathrm{LSD}=$ least significant difference. 
3 to $13 \%$ in 1995 and from 0 to $28 \%$ in 1996 , compared with a range of 6 to $16 \%$ reported by Trivellas (25) in studies in Georgia and Florida in 1981. Similarly, Romero and Sutton (18) reported that benomyl resistance persisted in populations of Mycosphaerella fijiensis in banana several years after the use of benomyl was stopped. Based on several parameters, they concluded that benomyl-resistant isolates of $M$. fijiensis were more aggressive than the isolates sensitive to benomyl. Our study did not address the relative aggressiveness or fitness of the sensitive and resistant isolates, but the existence of benomyl-resistant isolates in the peanut system this long after benomyl use ceased is circumstantial evidence that the general fitness of benomyl-resistant isolates of $C$. personatum is not greatly different from that of sensitive isolates.

Our results indicate that failures to control late leaf spot with benomyl alone are possible within the first season that benomyl alone is reintroduced into leaf spot control programs, even after long periods of peanut production without benomyl.

No difference in leaf spot control was noted between the two rates of benomyl by the time of the final evaluations. This is consistent with response of most fungi to varying rates of benomyl, and is in contrast to rate-related resistance that might be expected with $C$. personatum with SBI fungicides such as propiconazole or tebuconazole. Occurrences of populations of
Venturia inaequalis (13) and Cercospora beticola (11) that were resistant to low but not high rates of specific SBI fungicides have been reported. In our tests, either rate of benomyl alone provided suppression of leaf spot that, by late season, was similar to that of half rates of chlorothalonil alone at Tifton, but not at Plains, where final disease intensity was slightly lower than the nontreated plots.

Use of either alternate sprays of benomyl and chlorothalonil or full-season applications of tank mixes of half rates of those two fungicides provided control of leaf spot comparable to that achieved with full rates of chlorothalonil alone. Both the mixture and alternation regimes were better than full-season applications of beno-
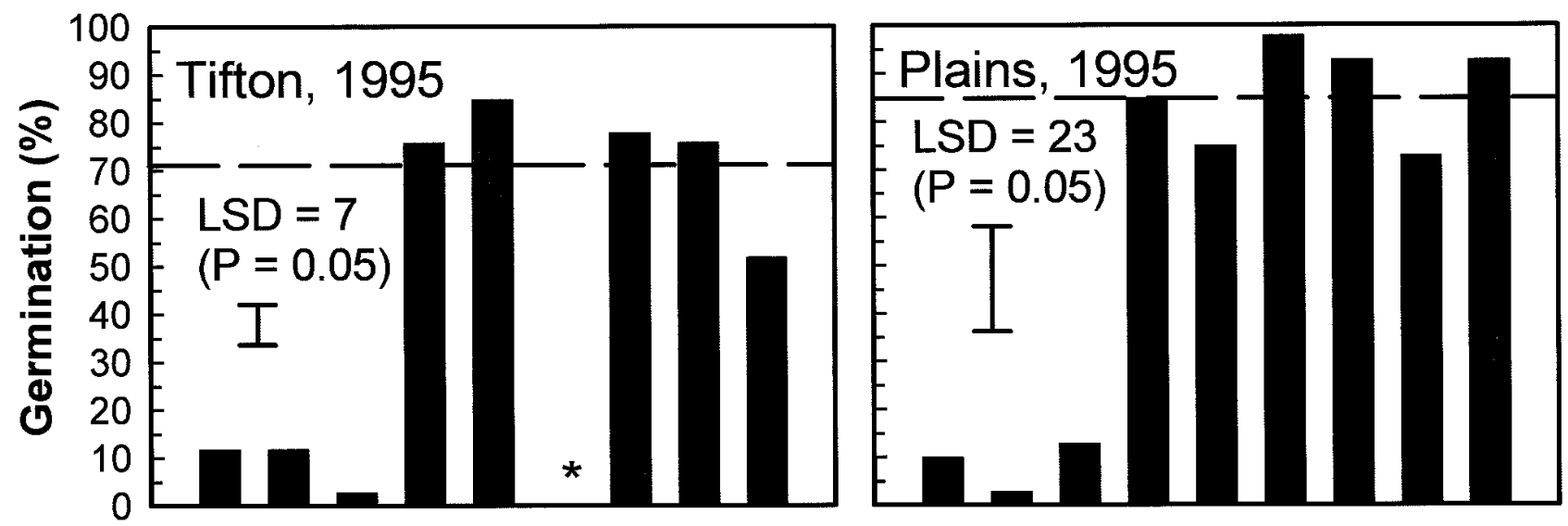

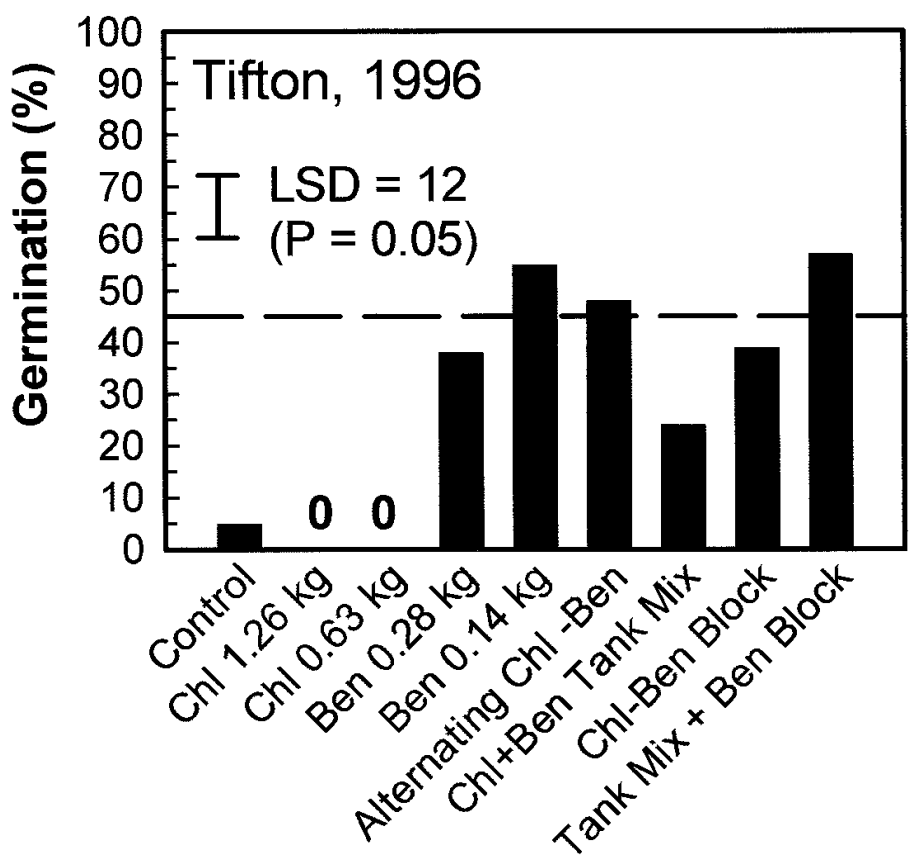

Fungicide treatment

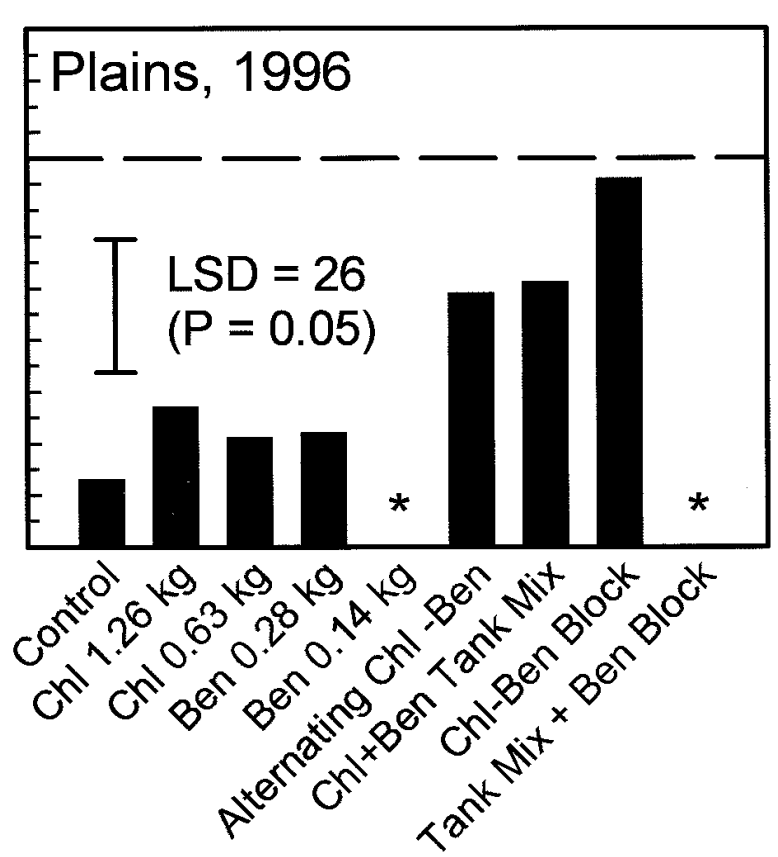

Fungicide treatment

Fig. 2. Effect of field treatment regimes of chlorothalonil (Chl) and benomyl (Ben) on percentage of conidia of Cercosporidium personatum that germinated on $2 \%$ water agar amended with benomyl at $0.5 \mu \mathrm{g} / \mathrm{ml}$. Treatments included: (i) no fungicide (Control); (ii) $\mathrm{Chl} \mathrm{at} 1.26 \mathrm{~kg} / \mathrm{ha}$; (iii) $\mathrm{Chl}$ at $0.63 \mathrm{~kg} / \mathrm{ha}$; (iv) Ben at $0.28 \mathrm{~kg} / \mathrm{ha}$; (v) Ben at $0.14 \mathrm{~kg} / \mathrm{ha}$; (vi) alternate sprays of Chl at $1.26 \mathrm{~kg} / \mathrm{ha}$ and Ben at $0.28 \mathrm{~kg} / \mathrm{ha}$ (Alternating Chl-Ben); (vii) mixtures of the chlorothalonil at $0.63 \mathrm{~kg} / \mathrm{ha}$ and benomyl at $0.14 \mathrm{~kg} / \mathrm{ha}(\mathrm{Chl}+\mathrm{Ben}$ Tank Mix), (viii) block applications of Chl at $1.26 \mathrm{~kg} / \mathrm{ha}$ and Ben at $0.28 \mathrm{~kg} / \mathrm{ha}(\mathrm{Chl}-$ Ben Block); and (ix)block applications of tank mixes of Chl at $0.63 \mathrm{~kg} / \mathrm{ha}$ and Ben at $0.14 \mathrm{~kg} / \mathrm{ha}$ followed by Ben at $0.28 \mathrm{~kg} / \mathrm{ha}$ and a final spray of Chl at $1.26 \mathrm{~kg} / \mathrm{ha}$ (Tank Mix + Ben Block). Dashed horizontal lines indicate the mean percentage of conidia from all treatments that germinated on $2 \%$ water agar without benomyl. An asterisk (*) indicates that too few conidia were recovered from plants receiving that treatment for comparison. A zero (0) indicates that no conidia from that treatment germinated on benomyl-amended agar. 
myl alone or alternating blocks of benomyl and chlorothalonil. Either alternations or mixture application regimes may allow preservation of the efficacy of systemic fungicides with specific-site modes of action for control of leaf spot, even in fields where significant portions of the pathogen population are have reduced sensitivity to that systemic fungicide.

Differences in final leaf spot intensity did not correspond with differences in yield in all tests. Duration of leaf spot intensity, especially when or if defoliation occurred, may be critical for leaf spot losses (1). Final leaf spot severity ratings did not indicate high levels of defoliation in any of the treatments that included fungicide applications at Tifton in either year. Although there were no consistent differences in stem rot incidence, yields may have been affected by nonuniform occurrence of this disease. The lack of effects of the benomyl treatments on incidence of stem rot is also notable in that it does not corroborate reports by Backman et al. (2) that benomyl could increase incidence of stem rot in peanut. In addition, tests in Tifton had significant infestations of spotted wilt, caused by Tomato spotted wilt virus. This disease limited yields, especially in 1995, and may have confounded potential fungicide effects on yield.

Köller and Scheinpflug (12) discussed the limitations of using a conventional fungicide such as chlorothalonil for resistance management; however, chlorothalonil is currently the only viable alternative to SBI or strobilurin chemistry for leaf spot control in peanut. Köller and Scheinpflug (12) also indicated no clear consensus concerning preference for the use of alternate sprays or tank mixes. Our results suggest that there is very little difference in control provided by these two regimes in this pathosystem. Staub (21) cited results from other pathosystems in which both tank mixes and alternations were superior to the use of single products for both efficacy and delaying shifts in sensitivity to SBI fungicides. Benomyl sensitivity assays of conidia from the various treatments in our tests provided no indication that either mixtures or alternations of benomyl with the protectant chlorothalonil prevented a shift to a much higher relative frequency of insensitivity than in plots receiving no benomyl.

However, the better disease control in plots treated with alternations or mixtures of benomyl and chlorothalonil compared with those treated with benomyl alone suggests that increase in the absolute frequency or total number of benomyl-resistant isolates may have been reduced.

Sutton et al. (24) reported that tank-mix combinations of reduced rates of nonbenzimidazole fungicides with benomyl did not provide adequate control of apple scab. In contrast, our results with tank mixes of half rates of chlorothalonil and benomyl corroborated previous reports $(1,20,25)$ of the efficacy of tank mixes of broader spectrum fungicides and benomyl for leaf spot control in peanut. Smith and Littrell (20) hypothesized that the use of mixtures of benomyl with mancozeb may have been responsible for the lack of problems with benomyl insensitivity in leaf spot pathogens of peanut in areas of Oklahoma and Texas where fungicides other than benomyl were needed for control of peanut rust (Puccinia arachidis) and web blotch (Phoma arachidicola). Backman et al. (1) reported numerical improvements in control of leaf spot and yield with use of mixtures of mancozeb and benomyl compared with benomyl at $0.21 \mathrm{~kg} / \mathrm{ha}$ alone, but yield was still approximately $700 \mathrm{~kg} / \mathrm{ha}$ less than with chlorothalonil at $1.26 \mathrm{~kg} / \mathrm{ha}$. They also reported that mixtures of benomyl at $0.14 \mathrm{~kg} / \mathrm{ha}$ and the protectant fungicide fentin hydroxide at $0.17 \mathrm{~kg} / \mathrm{ha}$ provided leaf spot control and yield comparable to that of chlorothalonil at $1.26 \mathrm{~kg} / \mathrm{ha}$ and better than that of benomyl alone at 0.21 $\mathrm{kg} / \mathrm{ha}$ (1). Trivellas (25) reported that control of late leaf spot in peanut plots treated with nonconsecutive applications of fullrate mixtures of chlorothalonil and benomyl, interspersed with chlorothalonil applications, was in most cases better than control in plots treated with full rates of chlorothalonil alone. Our results suggest that alternate applications of full rates of chlorothalonil and benomyl also would provide control similar to that obtained with full rates of chlorothalonil alone.

Littrell (14) reported that use of mixtures of benomyl at $14 \mathrm{~kg} / \mathrm{ha}$ with chlorothalonil at $1.1 \mathrm{~kg} / \mathrm{ha}$ resulted in a lower percentage of benomyl-resistant isolates of Cercospora arachidicola than full-season applications of benomyl alone. However, Trivellas (25) reported that two or more applications of benomyl, even applied with chlorothalonil, caused a dramatic increase in the frequency of isolates of Cercosporidium personatum that were resistant to benomyl. Our results corroborated the findings of Trivellas. In three of four tests, frequency of conidia of $C$. personatum resistant to benomyl at $0.5 \mu \mathrm{g} / \mathrm{ml}$ increased greatly in plots in which any benomyl was applied compared with plots where no fungicide or only chlorothalonil was applied. There was no indication that any of the fungicide regimes that included benomyl prevented an increase in the frequency of benomyl-resistant conidia compared with full-season use of benomyl alone. Although disease severity was low in treatments such as the mixtures or alternate spray regimes, the percentages of the benomyl-resistant conidia collected from leaves subjected to those treatments was as high as when benomyl was applied alone.

Our tests did not address how much leaf spot control was being provided by the chlorothalonil applications alone in the alternating sprays. In previous studies, use of chlorothalonil at $1.26 \mathrm{~kg}$ a.i./ha applied on a 21-day schedule resulted in a significant increase in intensity ratings of late leaf spot in two of three tests compared with the same rates applied on a 14-day schedule, even on a cultivar with moderate resistance to $C$. personatum (8). Based on those results, it is highly unlikely that leaf spot control comparable to full-season use of chlorothalonil could have been achieved had benomyl not contributed to disease control.

Köller and Wilcox (13) list two major goals for resistance management strategies. The first is to slow the rate at which resistant pathogen populations are selected to sizes large enough to cause unacceptable levels of disease in the presence of the respective fungicides. The second goal is to prevent resistant subpopulations from compromising commercially acceptable disease control once resistant phenotypes are selected to high frequencies. Although our results indicated that neither regime prevented a substantial increase in frequency of resistant individuals, both mixtures and alternations prevented the increased frequency of resistant isolates from reducing the level of disease control to an unacceptable level in the short term. These findings demonstrate the importance of a fungicide with multiple sites of action, such as chlorothalonil, for maintenance of efficacy of fungicides with more specific modes of action in situations where populations of pathogens with reduced sensitivity to those specific fungicides are present.

Problems with reduced sensitivity to propiconazole, tebuconazole, or azoxystrobin in peanut leaf spot pathogen populations have not been reported. Because of the polygenic control of resistance to SBI fungicides (9), the risk for developing problems in the peanut leaf spot systems is less with these fungicides than with the benzimidazole fungicides. However, reduced sensitivity to SBI fungicides have been reported in Cercospora beticola and M. fijiensis on sugar beet and banana, respectively $(9,17)$. Resistance to strobilurin fungicides appears to involve fewer genes (10) and may represent a greater threat for more rapid development of disease control problems attributable to reduced fungicide sensitivity.

Although we can only speculate how effective mixtures or alternations of these fungicides with chlorothalonil would be against Cercosporidium personatum or Cercospora arachidicola with reduced sensitivity to the SBI or strobilurin fungicides, the efficacy of chlorothalonil mixed or alternated with benomyl in our tests offers hope that these strategies could be effective for preserving control with other classes of site-specific fungicides as well.

Registration for benomyl has been withdrawn by the manufacturer. However, use of benomyl in this pathosystem represents a model for predicting the effect of fungi- 
cide use patterns for prolonging the effective utility of other fungicides to which foliar pathogen populations may develop resistance.

\section{ACKNOWLEDGMENTS}

We thank M. Heath for his essential efforts; and P. Bertrand, K. Chin, B. Kemerait, G. Hammes, H. Scherm, and T. Sutton. Dedicated to the memory of Ed Clark and Bob Littrell.

\section{LITERATURE CITED}

1. Backman, P. A., Rodríguez-Kábana, R., Hammond, J. M., Clark, E. M., Lyle, J. A., Ivey, H. W., II, and Starling, J. G. 1977. Peanut leaf spot research in Alabama 1970-1976. Auburn Univ. Agric. Exp. Stn. Bull. No. 489.

2. Backman, P. A., Rodríguez-Kábana, R., and Williams, J. C. 1975. The effect of peanut leaf spot fungicides on the non-target pathogen Sclerotium rolfsii. Phytopathology 65:773-776.

3. Brenneman, T. B., and Culbreath, A. K. 2000. Peanut disease control. Pages 96-97 in: 2000 Ga. Pest Control Handb. Univ. Ga. Coop. Ext. Serv. Special Bull. No. 28. P. Guillebeau, ed.

4. Brenneman, T. B., and Jewell, E. L.1988. In vitro fungicide sensitivity of Cercosporidium personatum. Proc. Am. Peanut Res. Educ. Soc. 20:32

5. Brent, K. J. 1995. Fungicide resistance in crop pathogens: How can it be managed? Fungic. Resist. Action Committee Monogr. No. 1. Global Crop Protection Federation, Brussels.

6. Chiteka, Z. A., Gorbet, D. W., Shokes, F. M., Kucharek, T. A., and Knauft, D. A. 988. Components of resistance to late leaf spot in peanut. I. Levels of variability-implications for selection. Peanut Sci. 15:25-30.

7. Clark, E. M., Backman, P. A., and RodríguezKábana, R. 1974. Cercospora and Cercosporidium tolerance to benomyl and related fungicides in Alabama peanut fields. Phytopathology 64:1476-1477.

8. Culbreath, A. K., Brenneman, T. B., and Kvien, K. C. 1992. Use of a resistant peanut cultivar with copper fungicides and reduced fungicide applications for control of late leaf spot. Crop Prot. 11:361-365.

9. Georgopoulos, S. G., and Skylakakis, G. 1986. Genetic variability in the fungi and the problem of fungicide resistance. Crop Prot. 5:299-305

10. Gisi, U., Chin, K. M, Knapova, G., Küng Färber, R., Mohr, U., Parisi, S., Sierotzki, H., and Steinfeld, U. 2000. Recent developments in elucidating modes of resistance to phenylamide, DMI, and strobilurin fungicides. Crop Prot. 19:863-872.

11. Karaoglanidis, G. S., Ioannidis, P. M., and Thanassoulopoulos, C. C. 2000. Reduced sensitivity of Cercospora beticola isolates to sterol-demethylation-inhibiting fungicides. Plant Pathol. 49:567-572.

12. Köller, W., and Scheinpflug, H. 1987. Fungal resistance to sterol biosynthesis inhibitors: A new challenge. Plant Dis. 71:1066-1074.

13. Köller, W., and Wilcox, W. F. 1999. Evaluation of tactics for managing resistance of Venturia inaequalis to sterol demethylation inhibitors. Plant Dis. 83:857-863.

14. Littrell, R. H. 1974. Tolerance in Cercospora arachidicola to benomyl and related fungicides. Phytopathology 64:1377-1378.

15. Porter, D. M. 1970. Effectiveness of benomyl in controlling Cercospora leaf spot of peanuts. Plant Dis. Rep. 54:955-958.

16. Rodríguez-Kábana, R., Backman, P. A., and Williams, J. C. 1975. Determination of yield losses to Sclerotium rolfsii in peanut fields. Plant Dis. Rep. 59:855-858.

17. Romero, R. A., and Sutton, T. B. 1997. Sensitivity of Mycosphaerella fijiensis, causal agent of black sigatoka of banana, to propiconazole. Phytopathology 87:96-100.
18. Romero, R. A., and Sutton, T. B. 1998. Characterization of benomyl resistance in $M y$ cosphaerella fijiensis, cause of black sigatoka of banana in Costa Rica. Plant Dis. 82:931934.

19. Shaner, G., and Finney, P. E. 1977. The effect of nitrogen fertilizer on expression of slow mildewing resistance in Knox wheat. Phytopathology 67:1051-1056.

20. Smith, D. H., and Littrell, R. H. 1980. Management of peanut foliar diseases with fungicides. Plant Dis. 64:356-360.

21. Staub, T. 1991. Fungicide resistance: Practical experience with antiresistance strategies and the role of integrated use. Annu. Rev. Phytopathol. 29:421-442.

22. Staub, T., and Sozzi, D. 1984. Fungicide resistance: A continuing challenge. Plant Dis. 68:1026-1031.

23. Steel, R. G. B., and Torrie, J. H. 1980. Principles and Procedures of Statistics. McGrawHill, New York.

24. Sutton, T. B. 1978. Failure of combinations of benomyl with reduced rates of nonbenzimidazole fungicides to control Venturia inaequalis resistant to benomyl and the spread of resistant strains in North Carolina. Plant Dis. Rep. 62:830-834.

25. Trivellas, A. E. 1988. Benzimidazole resistance monitoring techniques and the use of monitoring studies to guide benomyl marketing. Pages 28-30 in: Fungicide Resistance in North America. C. D. Delp, ed. American Phytopathological Society Press, St. Paul, MN.

26. Yoder, K. S., Davis, A. E., and Hadley, B. A. 1986. Monitoring resistance to benomyl in Venturia inaequalis, Monilinia spp., Cercospora spp., and selected powdery mildew fungi. Pages 73-75 in: Methods for Evaluating Pesticides for Control of Plant Pathogens. K. D. Hickey, ed. American Phytopathological Society Press, St. Paul, MN. 